\title{
Insulin secretory responses of a clonal cell line of simian virus 40-transformed B cells
}

\author{
S.J.H. Ashcroft, P. Hammonds and D. E. Harrison* \\ Nuffield Department of Clinical Biochemistry, John Radcliffe Hospital, Headington, Oxford, UK
}

\begin{abstract}
Summary. We have evaluated the potential of the clonal insulin-secretory cell line HIT-T15 as a model system for investigating stimulus-secretion coupling in pancreatic B cells. In contrast to other cell lines, HIT cell insulin secretion was consistently stimulated 2- to 3-fold by $\mathrm{D}$-glucose. The maximally effective concentration of glucose was $10 \mathrm{mmol} / \mathrm{l}$; between 2 and $10 \mathrm{mmol} / 1$ glucose the increase in insulin release was paralleled by an increased rate of glucose oxidation. The main characteristics of glucose-stimulated insulin release by HIT cells were essentially similar to those of normal islets. Thus, the response was (1) specific for metabolizable sugars (Dmannose and D-glyceraldehyde stimulated insulin release but L-glucose and D-galactose were ineffective); (2) markedly dependent on extracellular $\mathrm{Ca}^{2+}$ concentration; (3) potentiated by forskolin, glucagon, acetylcholine and 12-0-tetradecanoyl phorbol 13-acetate; (4) inhibited by adrenaline or somatostatin; (5) showed a biphasic pattern of release in perifusion
\end{abstract}

experiments, with both phases being potentiated by forskolin. The secretory response of the HIT cells to amino acids was also similar to that of normal islets. Thus, L-leucine and its deamination product 2-ketoisocaproate were effective stimuli, whereas L-isoleucine and L-glutamine were ineffective. Insulin release from HIT cells could also be evoked by the sulphonylureas glibenclamide and tolbutamide and by an increase in concentration of extracellular $\mathrm{K}^{+}$to $40 \mathrm{mmol} / \mathrm{l}$. The content of cyclic AMP in HIT cells was increased modestly by glucose but not by an increase in extracellular $\mathrm{K}^{+}$. Forskolin elicited a 4-fold increase in cyclic AMP content. We conclude that HIT cells retain the essential features of the insulin secretory response of normal $\mathrm{B}$ cells and represent an important tool for further biochemical characterisation of the secretory system.

Key words: Cell line, insulin secretion, HIT cells, B cells.
Biochemical characterisation of normal and pathological B cell function has been restricted by the limited availability and heterogeneity of isolated islets of Langerhans. The recent development of proliferative cell lines $[1,2]$ that can be grown in tissue culture to yield essentially unlimited amounts of tissue is therefore an important advance.

The clonal insulin-secreting cell line RIN-m5F [1] was developed from a transplantable rat insulinoma [3]. However, although RIN cells respond positively to certain insulin secretagogues, they fail to respond to glucose, the major physiological regulator of insulin secretion [4]. This lack of secretory response to glucose has been attributed to abnormal glucose metabolism in RIN cells [5].

In contrast, by transforming hamster islets with Simian virus 40, Santerre et al. [2] developed a glucose-

\footnotetext{
* Present address: CRC Medical Oncology Unit, Southampton General Hospital, Southampton, UK
}

responsive cell line (HIT cells). Preliminary characterisation of the HIT cell insulin secretory response also demonstrated stimulation by glucagon and 3-isobutyl1-methylxanthine (IBMX) and inhibition by somatostatin and dexamethasone [2]. Hill and Boyd [6] have characterised the dynamics of HIT cell insulin release stimulated by glucose, glucose + IBMX and $\mathrm{K}^{+}$; the same authors have recently shown [7] that the release of insulin evoked by glucose or by high $\mathrm{K}^{+}$is dependent on the presence of extracellular $\mathrm{Ca}^{2+}$. In addition, Swope and Schonbrunn [8] reported stimulation of basal and glucose-stimulated insulin release in HIT cells by bombesin, a gastrointestinal tetradecapeptide.

Despite these encouraging results, there has been no detailed survey of the secretory properties of HIT cells. Since this is essential for evaluation of the potential of HIT cells as a model for investigating the molecular basis of secretion, we have carried out a comprehensive study of the response of HIT cells to a range of hormones, nutrients and drugs known to modulate insulin 
secretion from normal islets. The interaction between the insulin secretory response to glucose and glucose metabolism and the relationship between intracellular cAMP content and insulin release were also studied.

\section{Materials and methods}

\section{Cell culture}

HIT cells (clone T15) were generously provided by Dr. A. E. Boyd III (Baylor College of Medicine, Houston, Texas, USA) and Dr. R.F. Santerre (Lilly Research Laboratories, Indianapolis, Ind, USA). For routine culture, $1.2 \times 10^{7}$ cells were seeded in $75 \mathrm{~cm}^{2}$ Costar tissue culture flasks (Horwell, London, UK) containing $40 \mathrm{ml}$ RPMI 1640 (Gibco Europe, Paisley, UK) supplemented with glucose (11 mmol/1) penicillin $(0.1 \mathrm{mg} / \mathrm{ml})$, streptomycin $(0.1 \mathrm{mg} / \mathrm{ml})$ and $10 \%(\mathrm{v} / \mathrm{v})$ heatinactivated foetal calf serum (Gibco). Cells were grown at $37^{\circ} \mathrm{C}$ in a humidified atmosphere of air: $\mathrm{CO}_{2}(95 \%: 5 \%)$. Culture medium was replaced every $48 \mathrm{~h}$ and cells were passaged at weekly intervals following detachment using Trypsin-EDTA (Gibco).

\section{Insulin secretion: static incubation}

HIT cells were passaged 2 days prior to each experiment and seeded at a density of $4 \times 10^{5}$ cells per well in 24-well Costar Multiwell plates. On the day of the experiment, culture medium was aspirated and cells were incubated at $37^{\circ} \mathrm{C}$ in $1 \mathrm{ml}$ of a modified Krebs bicarbonate medium [9] containing $20 \mathrm{mmol} / 1$ Hepes, $5 \mathrm{mg} / \mathrm{ml}$ bovine serum albumin (fraction V, Boehringer, Sussex, UK) and additions as listed in the Results section. At timed intervals, $150 \mu 1$ of incubation medium was removed, centrifuged briefly to sediment any detached cells, diluted in phosphate buffer $(40 \mathrm{mmol} / 1)$ containing albumin $(1 \mathrm{~g} / 1)$ and merthiolate $(6 \mathrm{mmol} / 1)$ and stored at $-20^{\circ}$ prior to assay. Insulin was measured by radioimmunoassay [10]. The maximum period of incubation was $1 \mathrm{~h}$, during which time the release of insulin was linear.

\section{Insulin secretion: perifusion}

The dynamics of HIT-T15 cell insulin secretion were investigated using a perifusion system similar to that described by Hill and Boyd [6]. $4 \times 10^{5}$ cells were seeded into individual wells in a 24-well Costar Multiwell plate containing an $18 \mathrm{~mm}$ Thermanox ${ }^{\mathrm{TM}}$ tissue culture cover slip (Flow Laboratories, Irvine, Ayrshire, UK). On reaching confluence $(72-96 \mathrm{~h})$, coverslips were transferred to $25 \mathrm{~mm}$ Swinnex Chambers, Millipore (Harrow, Middlesex, UK) and inserted into a perifusion chamber maintained at $37^{\circ} \mathrm{C}$. The flow rate was maintained at $1 \mathrm{ml} / \mathrm{min}$ using a peristaltic pump (Anachem, Luton, Bedfordshire, UK). The dead space of the perifusion system is $2 \mathrm{ml}$, with a corresponding lag time of $2 \mathrm{~min}$. Two-minute fractions were collected for analysis by radioimmunoassay. Swinnex chambers plus cells were preperifused for $1 \mathrm{~h}$ without glucose prior to receiving a 30-min stimulation period. Sample collection was started 50 -min into the preincubation period.

\section{Glucose oxidation}

Aliquots of $5 \times 10^{5}$ HIT cells were incubated for $1 \mathrm{~h}$ in a total volume of $50 \mu \mathrm{l}$ medium containing albumin $(5 \mathrm{mg} / \mathrm{ml})$ and $\mathrm{D}-\left[\mathrm{U}^{14} \mathrm{C}\right]$ glucose, specific radioactivity $3.5 \mathrm{dpm} / \mathrm{pmol}$ (Amersham International, Amersham, Bucks, UK) at concentrations from 2 to $20 \mathrm{mmol} / 1$. Glucose oxidation rates were determined by measuring ${ }^{14} \mathrm{CO}_{2}$ production as previously described [10].

\section{cAMP content}

Metabolism was arrested and cyclic AMP (cAMP) extracted by addition of $0.5 \mathrm{ml}$ hot acetate buffer $(50 \mathrm{mmol} / \mathrm{l})$. Samples were sonicated $(50 \mathrm{~W}, 10 \mathrm{~s})$ with a Soniprobe (Dawe Instruments, London, UK) and stored at $-20^{\circ} \mathrm{C}$ prior to assay. CAMP content was determined with a commercial radioimmunoassay kit (Amersham International) using an acetylation protocol.

\section{Reagents}

Tolbutamide and glibenclamide were a gift from Smith, Kline and French, Welwyn Garden City, Herts, UK. The phorbol ester 12-0-tetradecanoyl-phorbol 13-acetate (TPA) was purchased from PL Biochemicals, Northampton, UK. Forskolin and somatostatin were purchased from Calbiochem, Cambridge, UK. All other reagents were from British Drug House Chemicals, Poole, Dorset, UK or Sigma, Poole, Dorset, UK.

\section{Statistical analysis}

In order to combine and compare data from several experiments the following protocol was adopted for insulin secretion measurements. Every Multiwell plate always included 8 control wells containing cells incubated both in the absence ( 4 wells) and in the presence of $10 \mathrm{mmol} / 1$ glucose (4 wells). Release rates for test conditions were then expressed as a percentage of the mean value of the appropriate control rates in the same Multiwell plate and are given throughout as mean $\pm S E M$. For each test condition, duplicate or triplicate experiments were performed with 4 replicates per experiment. The mean absolute control values of insulin release over each series of experiments are also given. The significance of the effects of individual agents on HIT cell insulin release was assessed using Student's t-test.

The significance of the dependence on glucose concentration of rates of insulin release was determined using analysis of variance. Data are presented graphically as mean $\pm 95 \%$ confidence limits for the number of observations recorded.

\section{Results}

\section{Insulin secretory response to glucose in static incubations}

The amount of insulin secreted by HIT-T15 cells in culture varied considerably with time. Table 1 shows rates of insulin release in the absence and presence of glucose $(10 \mathrm{mmol} / 1)$ between passages 70 and 77 . The absolute levels of insulin secreted decreased somewhat with increasing time in culture (concomitant with decreasing insulin content) although glucose consistently doubled the basal secretory rate.

Figure 1 demonstrates the dose-response of glucosestimulated insulin release from HIT cells, which was shown by analysis of variance to be statistically significant $(p<0.001)$. A threshold glucose concentration of between 2 and $5 \mathrm{mmol} / 1$ was required for stimulation of insulin release. Maximal stimulation was observed at $10 \mathrm{mmol} / 1$ glucose, with a 2-fold stimulation between 5 and $10 \mathrm{mmol} / \mathrm{l}$ glucose. However, from $10-20 \mathrm{mmol} / 1$ glucose, the rate of insulin release fell to a level similar to that observed at $5 \mathrm{mmol} / 1$ glucose.

The rate of glucose oxidation was also increased between 2 and $10 \mathrm{mmol} / 1$ glucose. Glucose oxidation 
Table 1. Insulin content and release in HIT cells

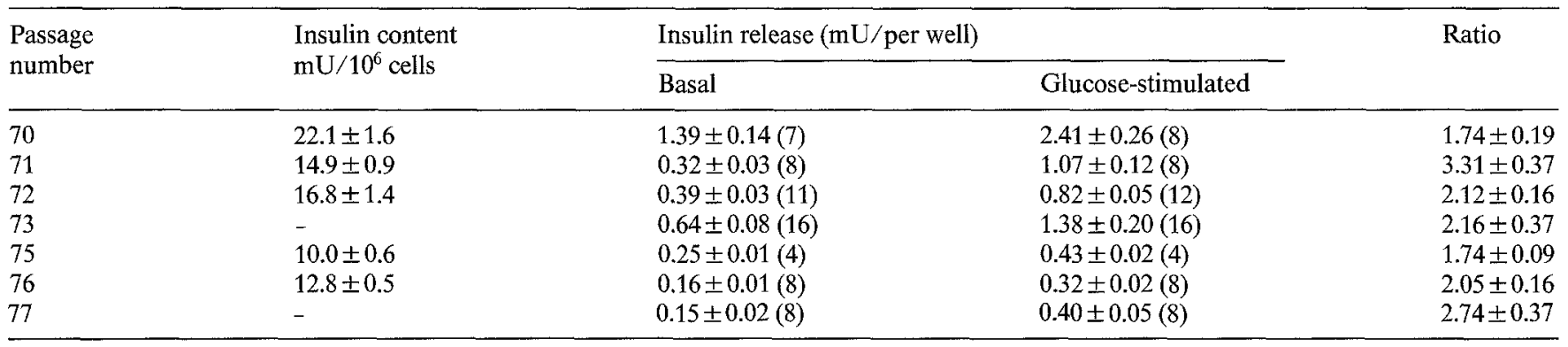

HIT cells $\left(4 \times 10^{5}-10^{6}\right.$ cells per well) were incubated at $37^{\circ} \mathrm{C}$ for $1 \mathrm{~h}$ in Hepes-buffered bicarbonate medium containing albumin $(5 \mathrm{~g} / 1)$ in the absence or presence of glucose $(10 \mathrm{mmol} / 1)$. The absolute rates of insulin release are given as mean $\pm S E M$ for the number of observations in parentheses. The ratio of stimulated to basal insulin release is also given as mean \pm SEM and was significantly $(p<0.001)$ greater than 1 at every passage number. For assay of cellular insulin content cells were disrupted by sonication and extracted in $0.1 \mathrm{~mol} / \mathrm{l} \mathrm{Na-borate} \mathrm{pH} 8 \mathrm{containing}$ albumin $(2 \mathrm{~g} / 1)$ and $0.5 \mathrm{~mol} / 1 \mathrm{NaCl}$

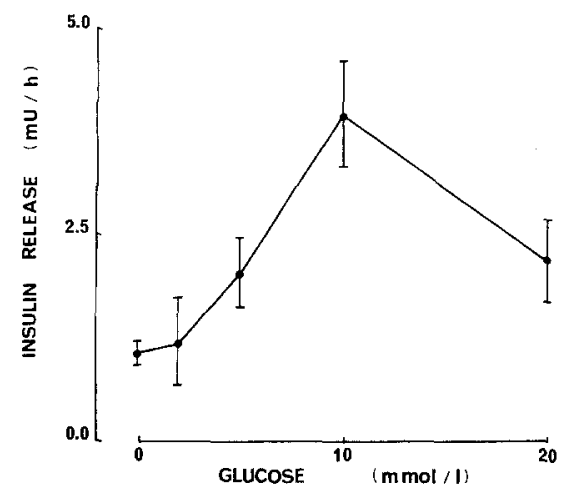

Fig. 1. Effect of glucose on HIT cell insulin release. HIT cells $\left(4 \times 10^{5}-10^{6}\right)$ were incubated at $37^{\circ} \mathrm{C}$ for $1 \mathrm{~h}$ in Hepes-buffered bicarbonate medium containing albumin $(5 \mathrm{~g} / 1)$ in the absence or presence of glucose $(2-20 \mathrm{mmol} / \mathrm{l})$. After $1 \mathrm{~h}$, aliquots were removed, centrifuged briefly and insulin released was assayed by radioimmunoassay. Data are presented as mean $\pm 95 \%$ confidence limits $(n=8)$. The dependence of insulin release on glucose concentration was significant by anovar $(p<0.001)$

rates (pmol $/ 10^{6}$ cells per $\mathrm{h}$; mean $\pm \mathrm{SEM}, n=3$ ) were $448 \pm 9,542 \pm 12$ and $689 \pm 8$ at 2.5 and $10 \mathrm{mmol} / 1$ glucose respectively.

\section{Calcium dependency of basal and glucose-stimulated insulin release}

Table 2 shows that glucose-stimulated insulin release from HIT cells was modulated by extracellular $\mathrm{Ca}^{2+}$ in a dose-dependent manner. In the absence of $\mathrm{Ca}^{2+}$, stimulation of insulin release by $10 \mathrm{mmol} / 1$ glucose was severely inhibited to a level significantly $(p<0.001)$ lower than than from cells incubated at $2.5 \mathrm{mmol} / 1 \mathrm{Ca}^{2+}$ in the absence of glucose. Neither 0.025 nor $0.25 \mathrm{mmol} / 1$ $\mathrm{Ca}^{2+}$ was sufficient to support glucose-stimulated insulin release. Raising $\mathrm{Ca}^{2+}$ to $0.5 \mathrm{mmol} / 1$ resulted in a rise in glucose-stimulated insulin release, although this was still significantly $(p<0.001)$ reduced compared to release at normal $\mathrm{Ca}^{2+}$ levels $(2.5 \mathrm{mmol} / 1)$. An increase in $\mathrm{Ca}^{2+}$ from 2.5 to $5.0 \mathrm{mmol} / 1$ resulted in a significant $(p<0.01)$ enhancement of glucose-stimulated insulin release.

\section{Initiation of insulin release}

The ability of various agents to initiate insulin release from HIT cells in the absence of other additions is summarised in Table 3.

In cells incubated with $10 \mathrm{mmol} / 1$ glucose the rate of insulin release was significantly greater $(p<0.001)$ than that seen in the absence of additions ( 2.5 -fold) or in the presence of $2 \mathrm{mmol} / 1$ glucose $(1.75$-fold). The addition of either L-glucose $(10 \mathrm{mmol} / \mathrm{l})$ or D-galactose $(10 \mathrm{mmol} / \mathrm{l})$ failed to cause any enhancement of insulin release above that seen in the absence of additions. However, both D-mannose $(10 \mathrm{mmol} / \mathrm{l})$ and D-glyceraldehyde $(10 \mathrm{mmol} / \mathrm{l})$ elicited insulin release to an extent not significantly different from that seen in the presence of $10 \mathrm{mmol} / 1$ glucose.

Stimulation of insulin release was also found in the presence of leucine $(20 \mathrm{mmol} / 1)$ or 2-ketoisocaproate acid $(10 \mathrm{mmol} / \mathrm{l})$. However, both glutamine $(20 \mathrm{mmol} / \mathrm{l})$ and isoleucine $(20 \mathrm{mmol} / \mathrm{l})$ proved ineffective.

The lowered insulin secretory rate seen in the absence of added nutrient was not attributable simply to an impairment of energy metabolism, since several nonnutrient secretagogues proved effective stimuli in the absence of glucose. Thus, raising the extracellular $\mathrm{K}^{+}$ level from 4.75 to $40 \mathrm{mmol} / 1$ provoked a marked stimulation of insulin release to a greater extent than seen with $10 \mathrm{mmol} / 1$ glucose. The adenylate cyclase activator forskolin $(10 \mu \mathrm{mol} / 1)$ was also a potent initiator of insulin release in the absence of glucose. Finally, the hypoglycaemic sulphonylureas tolbutamide $(1 \mathrm{mmol} / \mathrm{l})$ and glibenclamide $(20 \mu \mathrm{g} / \mathrm{ml})$ caused a marked stimulation of insulin release to levels in excess of that elicited by $10 \mathrm{mmol} / \mathrm{l}$ glucose.

\section{Modulation of glucose-stimulated insulin release}

Table 4 shows the effect of various agents on insulin release in the presence of $10 \mathrm{mmol} / 1$ glucose. Forskolin 
Table 2. Dependence of insulin secretion from HIT cells on extracellular $\mathrm{Ca}^{2+}$

\begin{tabular}{llll}
\hline Line & $\begin{array}{l}\text { Glucose } \\
(\mathrm{mmol} / \mathrm{l})\end{array}$ & $\begin{array}{l}\mathrm{Ca}^{2+} \\
(\mathrm{mmol} / \mathrm{l})\end{array}$ & $\begin{array}{l}\text { Insulin } \\
\text { release (\%) }\end{array}$ \\
\hline 1 & 10 & 2.5 & 100 \\
2 & 10 & 0 & $30 \pm 2(20)^{\mathrm{a}}$ \\
3 & 10 & 0.025 & $37 \pm 6(8)^{\mathrm{a}}$ \\
4 & 10 & 0.25 & $30 \pm 4(8)^{\mathrm{a}}$ \\
5 & 10 & 0.5 & $53 \pm 10(8)^{\mathrm{a}, \mathrm{d}}$ \\
6 & 10 & 1 & $64 \pm 6(12)^{\mathrm{a}, \mathrm{d}}$ \\
7 & 10 & 5 & $161 \pm 17(7)^{\mathrm{b}}$ \\
8 & 0 & 2.5 & $47 \pm 3(24)^{\mathrm{b}}$ \\
9 & 0 & 0 & $24 \pm 2(8)^{\mathrm{c}}$ \\
\hline
\end{tabular}

HIT cells were incubated in Multiwells in $1 \mathrm{ml}$ Hepes-buffered bicarbonate medium containing albumin $(5 \mathrm{~g} / \mathrm{l})$ and glucose and $\mathrm{Ca}^{2+}$ at the concentrations given. Medium containing zero $\mathrm{Ca}^{2+}$ also contained $10 \mu \mathrm{mol} / \mathrm{I}$ EGTA. After $1 \mathrm{~h}$ a sample of medium was briefly centrifuged to sediment any free floating cells and the insulin in the supernatant was measured by radioimmunoassay. In order to combine data from the complete series of experiments, every Multiwell plate included cells incubated under control conditions $(10 \mathrm{mmol} / 1$ glucose and $2.5 \mathrm{mmol} / 1 \mathrm{Ca}^{2+}$ ); release rates for each test condition were then calculated as a percentage of the mean release rate for the control wells in the same Multiwell plate, i. e. for cells of identical passage number and seeding density. Results are given as mean \pm SEM for the number of observations in parentheses. Over these experiments the mean absolute value of insulin release in control wells was $1.46 \pm 0.21 \mathrm{mU} /$ well $(n=23)$. Statistical significances of the observed differences in insulin release are: ${ }^{\mathrm{a}} p<0.001$ vs 1 ; $^{\mathrm{b}} p<0.01$ vs $1 ;^{\mathrm{c}} p<$ 0.001 vs $8 ;{ }^{\mathrm{d}} p<0.05$ vs 2

Table 3. Effects of agents on insulin release by HIT cells

\begin{tabular}{rlcc}
\hline Line & Addition & Concentration & $\begin{array}{l}\text { Insulin } \\
\text { release (\%) }\end{array}$ \\
\hline 1 & D-Glucose & $10 \mathrm{mmol} / 1$ & 100 \\
2 & None & - & $40 \pm 3(60)^{\mathrm{a}}$ \\
3 & D-Glucose & $2 \mathrm{mmol} / 1$ & $57 \pm 7(12)^{\mathrm{a}}$ \\
4 & D-Mannose & $10 \mathrm{mmol} / 1$ & $118 \pm 13(8)$ \\
5 & L-Glucose & $10 \mathrm{mmol} / 1$ & $29 \pm 6(8)^{\mathrm{a}}$ \\
6 & D-galactose & $10 \mathrm{mmol} / 1$ & $40 \pm 4(8)^{\mathrm{a}}$ \\
7 & D-glyceraldehyde & $10 \mathrm{mmol} / 1$ & $102 \pm 14(8)$ \\
8 & L-leucine & $20 \mathrm{mmol} / 1$ & $113 \pm 15(8)$ \\
9 & L-isoleucine & $20 \mathrm{mmol} / 1$ & $50 \pm 7(8)^{\mathrm{a}}$ \\
10 & 2-ketoisocaproate & $10 \mathrm{mmol} / 1$ & $81 \pm 13(8)$ \\
11 & L-glutamine & $20 \mathrm{mmol} / 1$ & $52 \pm 10(8)^{\mathrm{a}}$ \\
12 & K & $40 \mathrm{mmol} / 1$ & $268 \pm 42(12)^{\mathrm{b}}$ \\
13 & Forskolin & $10 \mathrm{mmol} / 1$ & $151 \pm 16(12)^{\mathrm{b}}$ \\
14 & Tolbutamide & $1 \mathrm{mmol} / 1$ & $186 \pm 40(8)^{\mathrm{b}}$ \\
15 & Glibenclamide & $20 \mu \mathrm{m} / \mathrm{ml}$ & $207 \pm 38(8)^{\mathrm{b}}$ \\
16 & Adrenaline & $10 \mathrm{mmol} / 1$ & $30 \pm 5(8)^{\mathrm{a}}$ \\
\hline
\end{tabular}

HIT cells were incubated in Multiwells for $60 \mathrm{~min}$ in $1 \mathrm{ml}$ Hepes-buffered bicarbonate medium containing albumin $(5 \mathrm{~g} / 1)$ and the additions stated. Insulin released into the medium was measured by radioimmunoassay. Every Multiwell plate included cells incubated with $10 \mathrm{mmol} / 1$ glucose. In order to combine data from the complete series of experiments, release rates for each condition were expressed as a percentage of the mean release rate in cells exposed to $10 \mathrm{mmol} / 1 \mathrm{glu}-$ cose in the same Multiwell plate. Results are given as mean \pm SEM for the number of observations given in parentheses. The mean absolute values of insulin release ( $\mathrm{mU} /$ well) from the control wells in the presence of $10 \mathrm{mmol} / 1$ glucose for this series of experiments was $1.24 \pm$ $0.12(n=52)$. Statistical significances of the observed differences in release rate under test conditions from that in the presence of $10 \mathrm{mmol} / 1$ glucose are: ${ }^{a}$ significantly $(p<0.001)$ less; ${ }^{b}$ significantly $(p<0.01)$ greater
Table 4. Effects of agents on glucose-stimulated insulin release from HIT cells

\begin{tabular}{lllll}
\hline Line & $\begin{array}{l}\text { Glucose } \\
(\mathrm{mmol} / \mathrm{l})\end{array}$ & $\begin{array}{l}\text { Other } \\
\text { additions }\end{array}$ & Concentration & $\begin{array}{l}\text { Insulin } \\
\text { release }(\%)\end{array}$ \\
\hline 1 & 10 & None & - & 100 \\
2 & 10 & Forskolin & $10 \mu \mathrm{mol} / 1$ & $386 \pm 35(8)^{\mathrm{a}}$ \\
3 & 10 & Acetylcholine & $10 \mu \mathrm{mol} / 1$ & $125 \pm 3(6)^{\mathrm{a}}$ \\
4 & 10 & TPA & $0.1 \mu \mathrm{mol} / 1$ & $400 \pm 87(8)^{\mathrm{b}}$ \\
5 & 10 & Glucagon & $5 \mu \mathrm{g} / \mathrm{ml}$ & $173 \pm 16(7)^{\mathrm{a}}$ \\
6 & 10 & Adrenaline & $5 \mu \mathrm{mol} / 1$ & $53 \pm 6(8)^{\mathrm{a}}$ \\
7 & 10 & Somatostatin & $5 \mu \mathrm{g} / \mathrm{ml}$ & $37 \pm 3(8)^{\mathrm{a}}$ \\
\hline
\end{tabular}

HIT cells were incubated with the additions shown as described in the legend to Table 2 . Insulin release measured by radioimmunoassay is expressed as a percentage of the mean rate observed with $10 \mathrm{mmol} / \mathrm{l}$ glucose in the same Multiwell plate. Data are given as mean $\pm S E M$ for the number of observations shown. For this series of experiments the mean absolute rate of insulin release in control wells with $10 \mathrm{mmol} / 1$ glucose was $1.63 \pm 0.145 \mathrm{mU} /$ well $(n=23)$; the mean rate of insulin release for cells incubated without additions was $40 \pm 3$ percent $(n=24)$ of the rate found in the presence of $10 \mathrm{mmol} / \mathrm{l}$ glucose. Significance of the differences between test and control $(10 \mathrm{mmol} / 1$ glucose) are: ${ }^{\mathrm{a}} p<0.001 ;{ }^{\mathrm{b}} p<0.01$

Table 5. Effect of secretagogues on intracellular cAMP levels

\begin{tabular}{lllc}
\hline Line & $\begin{array}{l}\text { [D-Glucose] } \\
(\mathrm{mmol} / 1)\end{array}$ & Other additions & $\begin{array}{c}\text { [cAMP] } \\
\left(\mathrm{pmol} / 10^{6} \mathrm{cells}\right)\end{array}$ \\
\hline 1 & - & - & $6.4 \pm 0.5$ \\
2 & - & Forskolin $(10 \mu \mathrm{mol} / \mathrm{l})$ & $24.4 \pm 4.6^{\mathrm{a}}$ \\
3 & 10 & - & $9.8 \pm 0.6^{\mathrm{b}}$ \\
4 & 10 & Forskolin $(10 \mu \mathrm{mol} / \mathrm{l})$ & $26.1 \pm 4.7^{\mathrm{c}}$ \\
5 & - & $\mathrm{K}^{+}(40 \mathrm{mmol} / \mathrm{l})$ & $5.3 \pm 0.4$ \\
\hline
\end{tabular}

After incubation for $1 \mathrm{~h}$ under the conditions shown, HIT cells were extracted and cyclic AMP content was determined by radioimmunoassay. Data are given as mean \pm SEM for four observations. Significance of the observed differences are: ${ }^{\mathrm{a}} p<0.05$ vs $1 ;{ }^{\mathrm{b}} p<0.01$ vs 1 ; ${ }^{c} p<0.05$ vs 3

$(10 \mu \mathrm{mol} / 1)$ potentiated glucose-stimulated insulin release almost 4-fold. Glucose-stimulated insulin release was also potentiated 4-fold by the phorbol ester TPA, by $10 \mu \mathrm{mol} / 1$ acetylcholine (1.3-fold) and by $5 \mu \mathrm{g} / \mathrm{ml}$ glucagon (1.7-fold). In contrast both adrenaline $(5 \mu \mathrm{mol} / 1)$ and somatostatin $(5 \mu \mathrm{g} / \mathrm{ml})$ caused marked inhibition of glucose-stimulated insulin release.

\section{Effect of various secretagogues on intracellular cAMP levels}

Table 5 shows the effect of various secretagogues on intracellular cAMP levels.

Raising the glucose concentration to $10 \mathrm{mmol} / 1$ caused a significant $(p<0.01)$ rise in cAMP from $6.4 \pm 0.5$ to $9.8 \pm 0.6 \mathrm{pmol} / 10^{6}$ cells, concomitant with a 2 -fold stimulation of insulin release (Table 1). Forskolin $(10 \mu \mathrm{mol} / \mathrm{l}$ induced a marked elevation of cAMP levels both in the absence of glucose and also at $10 \mathrm{mmol} / 1$ glucose. In contrast, the stimulation of insulin release by increased extracellular $\mathrm{K}^{+}$(Table 3 ) did not significantly alter intracellular cAMP levels. 


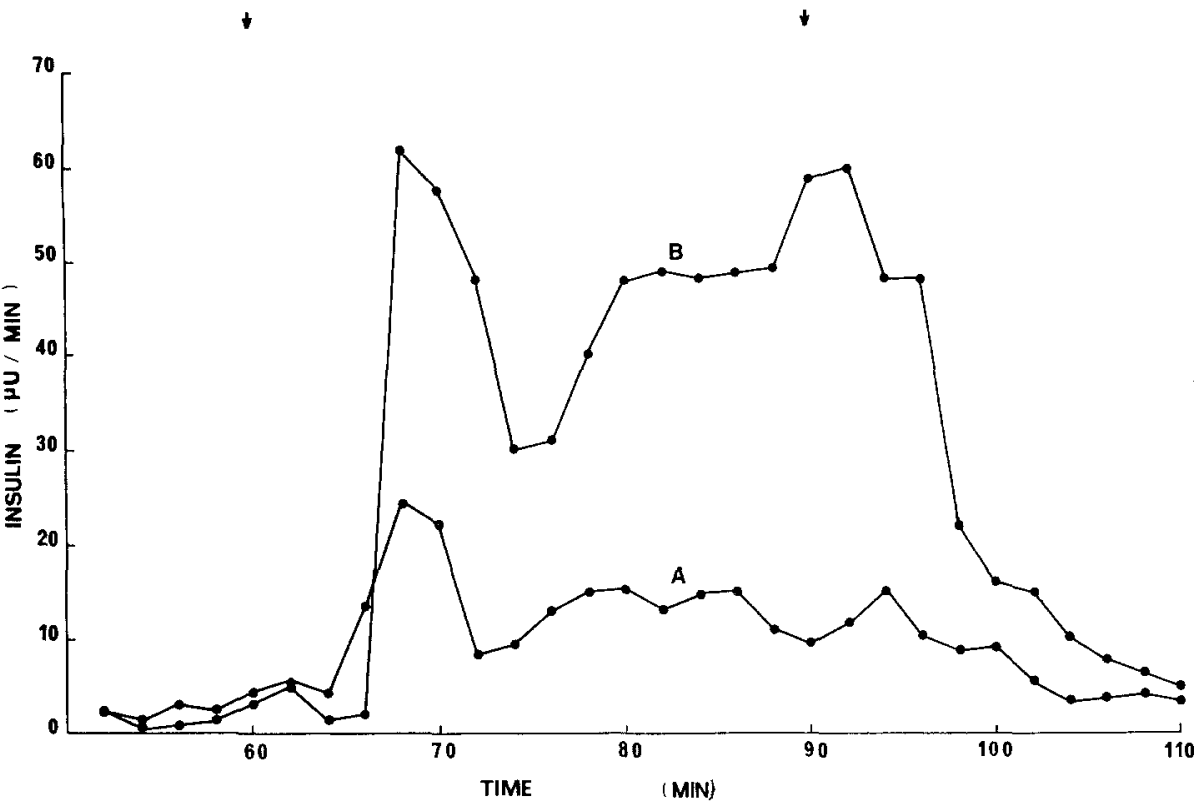

Fig. 2. Effect of glucose and glucose plus forskolin on HIT cell insulin secretory dynamics. HIT cells $\left(4 \times 10^{5}-10^{6}\right)$ were grown on coverslips and transferred to perifusion chambers. Cells were first perifused for a period of $60 \mathrm{~min}$ in basal medium with collection of fractions for insulin assay during the last $10 \mathrm{~min}$. The perifusion medium was then changed (first arrow) for one containing glucose $(10 \mathrm{mmol} / \mathrm{l})$ in the absence $(\mathrm{A})$ or presence (B) of forskolin $(10 \mu \mathrm{mol} / 1)$. After a 30-min stimulation period (second arrow) cells were again perifused with basal medium. The flow rate was $1 \mathrm{ml} / \mathrm{min}$, lag time $2 \mathrm{~min}$. The data shown are representative of three similar experiments

\section{Effect of glucose and glucose plus forskolin on the dynamics of HIT cell insulin release}

Figure 2 demonstrates the dynamics of glucose-stimulated insulin release and its potentiation by forskolin.

Preincubation for $1 \mathrm{~h}$ without glucose resulted in a steady baseline which was maintained in the absence of stimulation (data not shown). Stimulation by glucose $(10 \mathrm{mmol} / \mathrm{l})$ induced a biphasic secretory response. Taking into account a lag time of $2 \mathrm{~min}$ for the perifusion system, a first-phase peak insulin secretory rate of $24.5 \mu \mathrm{U} / \mathrm{min}$ was achieved $6 \mathrm{~min}$ after stimulation. During the next four min, the rate of secretion decreased rapidly but was followed by a second phase of secretion characterised by a lower insulin secretory rate (approximately $15 \mu \mathrm{U} / \mathrm{min}$ ) that was maintained (but did not continue to increase) for the duration of the glucose challenge. On removal of glucose, the insulin secretory rate returned to basal levels.

A combination of glucose $(10 \mathrm{mmol} / \mathrm{l})$ and forskolin $(10 \mu \mathrm{mol} / \mathrm{l})$ provoked a 4 -fold potentiation of glucosestimulated insulin release in HIT cells in static incubations. Figure 2 shows that this was characterised by potentiation of both phases of insulin secretion. Again, removal of the stimulus was characterised by a rapid return to basal secretion levels.

The data shown are representative of three similar experiments.

\section{Discussion}

The development of proliferative B-cell lines that retain the functional characteristics of normal islets would represent a significant advance in the study of the molecular basis of insulin secretion.
Previous studies $[2,6-8]$ have suggested a considerable potential for HIT cells as a model system for investigating stimulus-secretion coupling in pancreatic $B$ cells. The aim of the present investigation was to evaluate this potential by comprehensively surveying the secretory response of HIT cells to a range of nutrients, hormones and drugs known to modulate insulin release in normal islets.

In static incubations, 2- to 3-fold stimulation of HIT cell insulin release by glucose was consistently observed with a dose response curve similar to that for HIT cell glucose oxidation. The magnitude of the secretory response to glucose was lower than that of islets of Langerhans but was similar to that reported for dispersed islet cells [12]. The specificity of the secretory response to nutrients was essentially similar to that of normal islets; thus mannose, glyceraldehyde, leucine and 2-ketosocaproate elicited stimulation of insulin release whereas L-glucose, galactose, isoleucine and glutamine were ineffective. In contrast to Hill and Boyd [6, 7], who demonstrated a monophasic insulin response to glucose, we observed a biphasic secretory response to glucose in HIT cells that is typical of that found in normal islets.

Stimulation of insulin release by glucose depends on the presence of extracellular calcium ions. Glucose failed to stimulate insulin secretion from HIT cells when extracellular $\mathrm{Ca}^{2+}$ was less than $0.5 \mathrm{mmol} / 1$.

Using a different protocol, in which HIT cells were preincubated for $1 \mathrm{~h}$ in the absence of glucose and in the presence of varying $\mathrm{Ca}^{2+}$ concentrations and then stimulated with $19.7 \mathrm{mmol} / 1$ glucose at the same $\mathrm{Ca}^{2+}$ concentration, Boyd et al. [7] also demonstrated a similar dependency on the extracellular $\mathrm{Ca}^{2+}$ concentration of glucose-stimulated insulin release from HIT cells. Glucose-stimulated insulin secretion increased over the range 0.5 to $2.5 \mathrm{mmol} / 1 \mathrm{Ca}^{2+}$ but glucose did not stimu- 
late insulin release above basal rates (equivalent $\mathrm{Ca}^{2+}$ concentrations and no glucose) when glucose was added to zero or $0.1 \mathrm{mmol} / 1 \mathrm{Ca}^{2+}$ [7]. We find, in addition, that an elevation of extracellular $\mathrm{Ca}^{2+}$ from the normal 2.5 to $5 \mathrm{mmol} / 1$ caused an increased rate of glucose-induced insulin release. These data are consistent with the calcium dependency of islets, which show a threshold requirement of $0.1 \mathrm{mmol} / 1$ and maximum response between 5 and $10 \mathrm{mmol} / 1 \mathrm{Ca}^{2+}$ [13]. B-cell insulin release may be triggered by increasing the cytoplasmic $\mathrm{Ca}^{2+}$ concentration [14]. One method of achieving this is to depolarise cells by increasing the extracellular potassium concentration, which causes influx of calcium through voltage-sensitive calcium channels. Raising $\mathrm{K}^{+}$from 4.75 to $40 \mathrm{mmol} / \mathrm{l}$ resulted in a 6-fold stimulation of basal HIT cell insulin release in static incubations. Hill and Boyd [6] demonstrated a monophasic secretory response to $\mathrm{K}^{+}$in a perifusion system. Sulphonylureas with insulin-releasing effects also promote the entry of $\mathrm{Ca}^{2+}$ into B cells [15]. HIT cell insulin release was markedly stimulated by tolbutamide and glibenclamide. These findings suggest that the interaction between calcium and insulin release in HIT cells resembles that of normal islets.

Moreover, the ability of such non-nutrient secretagogues to initiate insulin release in the absence of glucose suggests that the lower insulin release seen in HIT cells incubated without additions is not attributable solely to a lack of exogenous nutrient.

Glucose-stimulated insulin release from HIT cells was inhibited by somatostatin or adrenaline as for islets of Langerhans [16]. Marked potentiation of glucose-stimulated insulin release was elicited by forskolin or glucagon, which may act by activation of cyclic AMP-dependent protein kinase [9]; by acetylcholine which may enhance turnover of inositol phospholipids [17]; and by a phorbol ester which has been shown to activate $\mathrm{Ca}^{2+}$-phospholipid-dependent protein kinase in B-cells [18] as in other cells [19]. These data suggest that HIT cells possess the full range of pathways for modulating insulin secretion previously demonstrated in islets of Langerhans.

The potent enhancement of insulin secretion seen in the combined presence of glucose and forskolin was further studied. In perifusion experiments the effect of forskolin was shown to involve potentiation of both phases of glucose-stimulated insulin release, and forskolin was shown to augment markedly the level of cyclic AMP in HIT cells. Elevation of cyclic AMP was not a necessary condition for insulin release since stimulation of insulin release by high $\mathrm{K}^{+}$concentration did not lead to any increase in HIT cell cyclic AMP. It is noteworthy that, as in islets of Langerhans [20], glucose itself, in the absence of forskolin, was able to elevate HIT cell cyclic AMP. When cyclic AMP was increased by forskolin, however, the simultaneous presence of glucose resulted in no detectable further increase in cyclic AMP but caused a 2-fold increase in insulin secre- tion (compare Table 3, line 13 with Table 4, line 2). Moreover, although forskolin was able to initiate insulin release in the absence of glucose, the magnitude of this response was only $50 \%$ greater than that of glucose despite the fact that cyclic AMP was increased 4-fold by forskolin but only $50 \%$ by glucose. These findings suggest that in HIT cells, as in islets of Langerhans [20], cyclic AMP plays a predominantly modulatory rather than initiatory role in the regulation of insulin release.

We conclude from these studies that HIT cells possess an insulin secretory response that retains the essential features of the normal differentiated B cell. The HIT cell line should therefore serve as an important source of material for further elucidation of the molecular mechanisms regulating insulin secretion.

Acknowledgements. These studies were supported by grants from the British Diabetic Association and the Medical Research Council. We thank Ms. M. Milewski, J. Chatterjee and H. Reed for expert technical assistance, Ms. G. Bates for typing this manuscript and Drs. A. E. Boyd III and R. F. Santerre for providing samples of HIT cells.

\section{References}

1. Gazdar AF, Chick WL, Oie HK, Sims HL, King DL, Weir GC, Lauris V (1980) Continuous, clonal insulin- and somatostatin-secreting cell lines established from a transplantable rat islet cell tumor. Proc Natl Acad Sci USA 77: 3519-3523

2. Santerre RF, Cook RA, Crisel RMD, Sharp JD, Schmidt RJ, Williams DC, Wilson CP (1981) Insulin synthesis in a clonal cell line of Simian virus 40-transformed hamster pancreatic beta cells. Proc Natl Acad Sci USA 78: 4339-4343

3. Chick WL, Warren S, Chute RN, Like AA, Lauris V, Kitchen KC (1977) A transplantable insulinoma in the rat. Proc Natl Acad Sci USA 74: 628 -632

4. Praz GA, Halban PA, Wollheim CB, Blondel B, Strauss AJ, Renold AE (1983) Regulation of immunoreactive-insulin release from a rat cell line (RINm5F). Biochem J 210:345-352

5. Halban PA, Praz GA, Wollheim CB (1983) Abnormal glucose metabolism accompanies failure of glucose to stimulate insulin release from a rat pancreatic cell line (RINm5F). Biochem J 212: $439-443$

6. Hill RS, Boyd III AE (1985) Perifusion of a clonal cell line of Simian virus 40 -transformed beta cells. Insulin secretory dynamics in response to glucose, 3-isobutylmethylxanthine and potassium. Diabetes 34: 115-120

7. Boyd III AE, Hill RS, Oberwetter AM, Berg M (1986) Calcium dependency and free calcium concentrations during insulin secretion in a hamster beta cell line. J Clin Invest 77: 774-781

8. Swope SL, Schonbrunn A (1984) Bombesin stimulates insulin secretion by a pancreatic islet cell line. Proc Natl Acad Sci USA 81: 1822-1866

9. Christie MR, Ashcroft SJH (1985) Substrates for cyclic AMP-dependent protein kinase in islets of Langerhans. Studies with forskolin and catalytic subunit. Biochem J 227: 727-736

10. Ashcroft SJH, Crossley JR (1975) Effects of glucose, N-acetylglucosamine, glyceraldehyde and other sugars on insulin release in vivo. Diabetologia 11:274-279

11. Ashcroft SJH, Hedeskov CJ, Randle PJ (1970) Glucose metabolism in mouse pancreatic islets. Biochem $J$ 118: 143-154

12. Pipeleers D (1984) Islet cell interactions with pancreatic B-cells. Experientia $40: 1114-1126$

13. Hellman B (1975) The significance of calcium for glucose stimulation of insulin release. Endocrinology $97: 392-398$ 
14. Wollheim CB, Sharp GWA (1981) Regulation of insulin release by calcium. Physiol Rev 61: 914-973

15. Gylfe E, Hellman B, Sehlin J, Taljedal IB (1984) Interaction of sulphonylureas with the pancreatic B-cell. Experientia 40:1126-1134

16. Smith PH, Porte JRD, Robertson RP (1979) Neural regulation of the endocrine pancreas. In: Pierlussi J (ed) Endocrine pancreas and diabetes. Excerpta Medica, Amsterdam, pp 64-95

17. Best L, Dunlop M, Malaisse WJ (1984) Phospholipid metabolism in pancreatic islets. Experientia 40: 1075-1084

18. Harrison DE, Ashcroft SJH, Christie MR, Lord JM (1984) Protein phosphorylation in the pancreatic B-cell. Experientia 40: 1075-1084

19. Castagna M, Takai Y, Kaibuchi K, Sano K, Kikkawa U, Nishizuka Y (1982) Direct activation of calcium-activated, phospholipiddependent protein kinase by tumour-promoting phorbol esters. J Biol Chem 257: 7847-7851
20. Christie MR, Ashcroft SJH (1984) Cyclic AMP-dependent protein phosphorylation and insulin secretion in intact islets of Langerhans. Biochem J 218: 87-99

Received: 14 March 1986

and in revised form: 28 August 1986

Dr. S.J.H. Ashcroft, Nuffield Department of Clinical Biochemistry John Radcliffe Hospital,

Headington,

Oxford OX3 9DU

UK 